\title{
The prevalence of resistant and undercontrolled hypertension among patients of a Hypertension Outpatient Clinic
}

\author{
Imola Fejes, György Ábrahám, Péter Légrády \\ $1^{\text {st }}$ Department of Medicine, University of Szeged, Szeged, Hungary
}

\begin{abstract}
Introduction. Around 57\% of Hungarian hypertensive patients did not reach the goal blood pressure. According to an ESH Newsletter published in 2011, the prevalence of resistant hypertension is 2.9-43\%.

Objective. Analysing only the therapy of hypertensive patients of the Hypertension Outpatient Clinic of the University of Szeged, the authors wanted to answer following main questions: How many patients were therapeutically resistant according to the definition of resistant hypertension? How many patients were taking 3 or more antihypertensive drugs? How many of these patients reached target SBP values? How many drugs were usually used in combination therapy?

Material and methods. Data were retrospectively collected from 01/01/2011 to 31/08/2011 from the electronic files of the hypertensive patients. Altogether 310 patients' data were analysed, of all cases only one visit was taken into account. For those patients who visited the Clinic more than once during this period, only the first visit was considered. Means of two measurements were calculated. The goal SBP was $140 \mathrm{mmHg}$.

Results. In this population, $234 / 310$ (76\%) patients had resistant hypertension according to the definition (158 \pm $17 / 97 \pm 8 \mathrm{mmHg})$. Three or more antihypertensive drugs were taken by $257 / 310(83 \%)$ patients $(136 \pm 20 \mathrm{mmHg})$ and 134 of them ( $52 \%$ of 257 patients) reached the therapeutic goal. A fourfold combination of antihypertensive agents was the most frequent in this population.

Conclusion. It is advised to use multiple drug combinations and it is recommended to spend enough time but not longer than necessary to find the most effective combination in every case.
\end{abstract}

key words: resistant, hypertension, combination

Arterial Hypertens. 2017, vol. 21, no. 2, pages: 69-72

DOI: $10.5603 / A H .2017 .0009$

\section{Background}

In Hungary, the number of adult hypertensive patients (age > 19 year) registered in General Practitioner system had been doubled between 1999 and 2011 from 1608202 to 3482000 [1]. Hyperten-

Address for correspondence: Imola Fejes, MD $1^{\text {st }}$ Department of Medicine, University of Szeged Hungary, Szeged, Koranyi fasor 8-10

H-6720

e-mail: fejesimola@yahoo.com

V M Copyright @ 2017 Via Medica, ISSN 2449-6170 sion (HT) is poorly controlled not only in Hungary, but also in Europe and worldwide. As reported in a paper based on data from 2005 to 2009, around $57 \%$ of Hungarian hypertensive patients did not reach the goal blood pressure (BP) [2].

According to the 2013 definition by the European Society of Hypertension (ESH) and the European Society of Cardiology (ESC), HT is considered as therapeutically resistant (RHT) when an appropriate lifestyle modification with a triple antihypertensive drug combination (a diuretic and two other antihypertensive drugs belonging to different classes, but 
not necessarily including a mineralocorticoid receptor antagonist) at adequate doses fail to lower systolic blood pressure (SBP) and diastolic blood pressure (DBP) values to < 140 and $90 \mathrm{mmHg}$ [3]. Patients whose BP is controlled, but with 4 or more medications, are considered to have RHT [4, 5]. In 2007, hypertension was defined as resistant or refractory to treatment when implementing lifestyle measures and at least three drugs (including a diuretic) in adequate doses has failed to lower SBP and DBP to goal values [6].

The real prevalence of RHT is not known; it varies over a wide range depending on the definition of RHT and goal BP values used at different data collection locations, the population examined and the level of medical screening (etc. work place, general practitioner [GP] office, hospital, clinic, HT centre, and so on). The prevalence of RHT in GP offices is suggested to be less than $5 \%$ of the overall HT population, while in clinical trials $10-20 \%$ and in HT centres it may be much more higher [7]. According to an ESH Newsletter published in 2011, the prevalence of RHT is $2.9-43 \%$ [8].

In 2009, the reappraisal of European guidelines recommended that SBP should be lowered to $<140 /$ $/ \mathrm{mmHg}$ in both low to moderate and high risk HT patients [9].

\section{Material and methods}

The authors analysed data of HT patients registered in one of the Hypertension Outpatient Clinics of the 1st Department of Medicine Nephrology-Hypertension Centre, University of Szeged, Hungary. Analysing only the therapy of HT patients, the authors wanted to answer following main questions: How many patients were taking 3 or more antihypertensive drugs? How many of these patients reached the goal SBP values? How many patients were therapeutically resistant according to the definition of RHT? How many drugs were usually used in combination therapy? In this work, the authors did not investigate the possible causes of RHT or any correlations between the number of drugs and BP values.

Data were retrospectively collected from 01/01/2011 to 31/08/2011 from the electronic files of the HT patients. Altogether 310 patients' data were analysed; for all cases only one visit was taken into account. For those patients who visited the Clinic more than once during this period, only the first visit was considered. Blood pressure measurements were performed by an OMRON 705IT automatic BP monitor. Means of two measurements were cal- culated. The goal SBP was $140 \mathrm{mmHg}$, as it was recommended in the 2009 reappraisal of European guidelines [9].

The authors used only descriptive statistics and means $\pm S D$ are reported.

\section{Results}

The mean age of HT patients was $61.4 \pm 14.3$ years. The mean duration of HT was $14.2 \pm 12.0$ years. Among these $310 \mathrm{HT}$ patients, 115 (37\%) were men (age $58.2 \pm 15.6$ years) and 195 (63\%) were women (age $63.4 \pm 13.1$ years). By office BP readings the BP of $186 / 310(60 \%)$ patients were in the goal range (SBP $124 \pm 9 \mathrm{mmHg}$ ) and 124/310 (40\%) were not (SBP $155 \pm 17 \mathrm{mmHg}$ ).

Among the 310 patients, 45 (15\%) had only diabetes mellitus (DM) as additional risk factor, type 1 and type 2 together. Twenty-one (17\%) of $124 \mathrm{HT}$ patients with undercontrolled BP $(149 \pm 15 / 89 \pm$ $8 \mathrm{mmHg}$ ) had DM.

According to the definition of RHT, altogether $234 / 310(76 \%)$ patients had RHT in this population. The mean BP of these patients was $158 \pm 17 / 97$ $\pm 8 \mathrm{mmHg}$. However 257/310 (83\%) patients were taking 3 or more antihypertensive drugs, and their $\mathrm{SBP}$ was $136 \pm 20 \mathrm{mmHg}$. The difference $(\mathrm{n}=23)$ between 257 and 234 were the patients who were prescribed 3 drugs and reached the goal SBP. Altogether 174 patients were taking 4 or more drugs and 111 of them (47\% of 234 RHT patients) had SBP $<140 / \mathrm{mmHg}$ and 63 (27\% of 234 RHT patients) of them didn't reach the goal SBP.

Among the multiple-drug combinations, 83/310 (27\%) patients were taking 3 antihypertensive drugs, 65/310 (21\%) were taking 4 drugs, 48/310 (15\%) were taking 5 drugs, $34 / 310$ (11\%) were taking 6 drugs, 20/310 (6\%) were taking 7 drugs and 7/310 (2\%) were taking 8 drugs.

Table I summarizes the different drug combinations and respective SBP values.

Fifteen patients were on monotherapy; their BP was $124 \pm 12 / 79 \pm 9 \mathrm{mmHg}$, and only 1 of them was undercontrolled (BP 154/100 $\mathrm{mmHg}$ ). All the patients taking 2 drugs (38/310) were in the goal range.

Table II summarizes the distribution of different antihypertensive agents in this population. Forty-one patients were not taking any renin-angiotensin system inhibitor. Nobody was taking direct renin inhibitor.

Altogether in $123 / 310(40 \%)$ patients BP was undercontrolled; $60 \%$ of all the patients were in the goal BP range. 
Table I. The different antihypertensive drug combinations and systolic blood pressure values (mean \pm SD)

\begin{tabular}{|l|c|c|c|}
\hline $\begin{array}{l}\text { Number of drugs } \\
\text { combined }\end{array}$ & Patients by goal & $\begin{array}{c}\text { SBP } \\
{[\mathrm{mmHg}]}\end{array}$ & \\
\hline 3 & All & $136 \pm 18$ & $\mathrm{n}=83$ \\
\cline { 2 - 4 } & Resistant & $155 \pm 13$ & $\mathrm{n}=60$ \\
\cline { 2 - 4 } & Controlled & $124 \pm 9$ & $\mathrm{n}=23$ \\
\hline \multirow{4}{*}{4} & All & $135 \pm 21$ & $\mathrm{n}=65$ \\
\cline { 2 - 4 } & Resistant & $157 \pm 19$ & $\mathrm{n}=22$ \\
\cline { 2 - 4 } & Controlled & $124 \pm 10$ & $\mathrm{n}=43$ \\
\hline 5 & All & $131 \pm 14$ & $\mathrm{n}=48$ \\
\cline { 2 - 4 } & Resistant & $150 \pm 8$ & $\mathrm{n}=13$ \\
\cline { 2 - 4 } & Controlled & $124 \pm 8$ & $\mathrm{n}=35$ \\
\hline 6 & All & $145 \pm 26$ & $\mathrm{n}=34$ \\
\cline { 2 - 4 } & Resistant & $167 \pm 19$ & $\mathrm{n}=16$ \\
\cline { 2 - 4 } & Controlled & $126 \pm 11$ & $\mathrm{n}=18$ \\
\hline 7 & All & $139 \pm 20$ & $\mathrm{n}=20$ \\
\cline { 2 - 4 } & Resistant & $156 \pm 17$ & $\mathrm{n}=9$ \\
\cline { 2 - 4 } & Controlled & $126 \pm 7$ & $\mathrm{n}=11$ \\
\hline 8 & All & $147 \pm 21$ & $\mathrm{n}=7$ \\
\cline { 2 - 4 } & Resistant & $161 \pm 15$ & $\mathrm{n}=3$ \\
\cline { 2 - 4 } & Controlled & $129 \pm 8$ & $\mathrm{n}=4$ \\
\hline
\end{tabular}

\section{Discussion}

The prevalence of target organ damages such as left ventricular hypertrophy, retinopathy, microalbuminuria and increased arterial intima-media thickness are $50-100 \%$ higher in true RHT compared to well-controlled hypertensives. The risk of cardiovascular diseases is also $2.5-5$ times higher $[10,11]$.

In Hungary in 2007 the BP of $46 \%$ of the nondiabetic HT population and only $8.5 \%$ of the diabetic HT population was in the goal range [12]. During the follow-up in the program "Live Under 140/90" the proportion of patients reaching the goal $\mathrm{BP}$ range had been continuously improved: in 2004 it was $27 \%$, in $2005-39 \%$, in $2007-44 \%$ and in 2010 - 48-58\% [13]. In a Hungarian pilot study enrolling $46000 \mathrm{HT}$ patients, BP over the goal range most frequently was observed in the age groups of 50-59 (25.4\%) and 60-69 (28.7\%) years. In this study the mean BP over the goal range was 160-179/100-109 $\mathrm{mmHg}$ in $45.6 \%$ and $140-159 / 90-99 \mathrm{mmHg}$ in $43.8 \%$ [14].

In this observational study the proportion of HT patients with BP in the goal range was quite high $(60 \%)$, but obviously the percentage of patients prescribed a combination of three or more
Table II. The distribution of different antihypertensive agents (ACEI $=$ angiotensin converting enzyme inhibitor, $A R B=$ angiotensin receptor 1 blocker, $\mathrm{BB}=$ beta-blocker, $\mathrm{DHP}-\mathrm{CCB}=$ dihydropiridine calcium-channel blocker, l-agonist = imidazoline-receptor agonist)

\begin{tabular}{|l|c|}
\hline Antihypertensive agents & Number of patients \\
\hline ACEI & 179 \\
\hline ARB & 90 \\
\hline ACEI + ARB & 13 \\
\hline Thiazide diuretics & 212 \\
\hline Other diuretics & 104 \\
\hline Thiazide + other diuretics & 77 \\
\hline Other BB & 116 \\
\hline Vasodilator BB & 106 \\
\hline DHP-CCB & 206 \\
\hline I-agonist & 87 \\
\hline Central acting & 53 \\
\hline Alpha-blocker & 98 \\
\hline Direct vasodilator & 5 \\
\hline non-DHP-CCB & 5 \\
\hline
\end{tabular}

drugs was also very high (83\%). Monotherapy was sufficient to reach the goal BP only in $4.8 \%$. On the other hand, the prevalence of RHT by definition (and not the prevalence of true RHT) was also quite high $(76 \%)$. These data accords with the observations that in specific HT centres the prevalence of RHT is higher. Of course not all the HTs diagnosed as RHT are true ones. The very first thing that is recommended in patients with RHT suspicion is to exclude the white coat HT and/or white coat effect with a 24-hour ambulatory blood pressure monitoring and exclude pseudoresistant HT by checking in hospital whether the patient is really taking the antihypertensive medications. After exclusion these, it is necessary to clear up any possible factors interfering with the therapy and find possible secondary causes of HT. Finally the therapy should be optimized. If BP is still not in the goal range after these procedures, than this $\mathrm{BP}$ is a true resistant one.

A fourfold combination of antihypertensive agents was the most frequent in this population. The most frequent drug classes were the ACEIs and/or ARBs, the DHP-CCBs and the thiazide diuretics.

In this population, 26 patients $(8 \%$ of all HT patients and $11 \%$ of RHT patients) had a secondary cause of RHT known at the time of data collection, other than DM. 


\section{Conclusion}

In patients with RHT, the prevalence of so called identifiable causes is fourfold higher than in non-RHT patients [15]. Pseudoresistant and secondary HT forms are usually tractable, and they can be converted to a controlled form of HT. It is advised to use multiple drug combinations and it is recommended to spend enough time but not longer than necessary to find the most effective combination in every case. If there is no any contraindication, a threefold combination of ACEI + DHP-CCB + thiazide diuretic is a basic treatment to reach the goal $\mathrm{BP}$.

\section{References}

1. Szegedi J, Kékes E, Sonkodi S, et al. A hypertonia epidemiológiája Magyarországon. Hypertonia és Nephrologia. 2014; 18(5-6): 134-143.

2. Kékes E, Kiss I, Pál L. A magyar hipertóniás populáció gyógyszeres kezelésének gyakorlata négy év távlatában (2005-2009). Háziorv Továbbk Szle. 2010; 15(9): 594-599.

3. Mancia G, Fagard R, Narkiewicz K, et al. 2013 ESH/ESC Guidelines for the management of arterial hypertension The Task Force for the management ofarterial hypertension of the European Society of Hypertension (ESH) and of the European Society of Cardiology (ESC). J Hypertens. 2013; 31: 1281-1357, doi: 10.1097/01. hjh.0000431740.32696.cc, indexed in Pubmed: 23817082.

4. Calhoun DA, Jones D, Textor S, et al. Resistant Hypertension: Diagnosis, Evaluation, and Treatment: A Scientific Statement From the American Heart Association Professional Education Committee of the Council for High Blood Pressure Research. Circulation. 2008; 117(25): e510-e526, doi: 10.1161/circulationaha.108.189141.

5. Viera AJ. Resistant Hypertension. J Am Board Fam Med. 2012; 25(4): 487-495, doi: 10.3122/jabfm.2012.04.110275.
6. Mancia G, De Backer G, Dominiczak A, et al. 2007 Guidelines for the Management of Arterial Hypertension. The Task Force for the Management of Arterial Hypertension of the European Society of Hypertension (ESH) and of the European Society of Cardiology (ESC). J Hypertens. 2007; 25(6): 1105-1187, doi: $10.1097 /$ HJH.0b013e3281fc975a, indexed in Pubmed: 17563527.

7. Garg JP, Elliott WJ, Folker A, et al. RUSH University Hypertension Service. Resistant hypertension revisited: a comparison of two university-based cohorts. Am J Hypertens. 2005; 18(5 Pt 1): 619-626, doi: 10.1016/j.amjhyper.2004.11.021, indexed in Pubmed: 15882544.

8. Erdine S, Arslan E, Coca A. Resistant hypertension. European Society of Hypertension Scientific Newsletter: Update on Hypertension Management. 2011; 12(15).

9. Mancia G, Laurent S, Agabiti-Rosei E, et al. European Society of Hypertension. Reappraisal of European guidelines on hypertension management: a European Society of Hypertension Task Force document. J Hypertens. 2009; 27(11): 2121-2158, doi: $10.1097 /$ HJH.0b013e328333146d, indexed in Pubmed: 19838131.

10. Cuspidi C, Macca G, Sampieri L, et al. High prevalence of cardiac and extracardiac target organ damage in refractory hypertension. J Hypertens. 2001; 19(11): 2063-2070, indexed in Pubmed: 11677373.

11. Isaksson $\mathrm{H}$, Ostergren J. Prognosis in therapy-resistant hypertension. J Intern Med. 1994; 236(6): 643-649, indexed in Pubmed: 7989899.

12. Kékes E, Schanberg Zs, Kiss I. Hogyan értékeljük társadalmi szinten a magas vérnyomás kezelését az "Éljen 140/90 alatt" mozgalom keretében? Hypertonia és Nephrológia. 2007; 11: 232-236.

13. Kiss I, Kékes E. A hypertoniás betegek célvérnyomás-elérési arányának és gondozási minőségének segítése telemedicinális lehetőségek alkalmazásával. Hypertonia és Nephrologia. 2012; 16(6): 243-245.

14. Ábrahám Gy. Az ajánlások érvényesülése a hazai magasvérnyomás-betegek kezelésében: a HERCULES (Hungarian HypERtensive Patients' Treatment in line with CUrrent Therapeutical GuideLine Study) vizsgálat első eredményei. Háziorv Továbbk Szle. 2012; 17(7): 420-425.

15. Gonzalez-Santos L, Elliott WJ, Setaro JF. Resistant hypertension. In: Black HR, Elliott WJ. ed. Hypertension. A Companion to Braunwald's Heart Disease. 2nd edition. Elsevier Saunders 2012: 378-384. 